\title{
Effect of deslorelin implants on follicular development, parturition and post-partum oestrus in the tammar wallaby (Macropus eugenii)
}

\author{
C A Herbert, T E Trigg ${ }^{1}$ and D W Cooper \\ Department of Biological Sciences, Macquarie University, North Ryde, New South Wales 2109, Australia and \\ ${ }^{1}$ Peptech Animal Health, Locked Bag No. 2053, North Ryde, New South Wales 2113, Australia \\ Correspondence should be addressed to Catherine A Herbert; Email: cherbert@rna.bio.mq.edu.au
}

\begin{abstract}
The effect of treatment with slow release implants containing the GnRH agonist, deslorelin, was investigated in female tammar wallabies. Pouch young were removed from 16 wallabies presumed to be carrying quiescent blastocysts. Eight received a $\mathbf{5} \mathrm{mg}$ deslorelin implant and eight received a placebo implant. Animals were caught daily from day 25 to day 30 and their pouches inspected for newborn young and their urogenital sinus checked for a copulatory plug. Treatment with deslorelin did not affect reactivation of a dormant blastocyst and subsequent birth in $4 / 8$ animals, but post-partum mating was inhibited in these animals. Five control and five treated animals were killed within $0-48 \mathrm{~h}$ post partum and their reproductive tracts analysed. At autopsy, all five control animals had large preovulatory follicles but only one deslorelin-treated animal showed signs of follicular development. These differences were also reflected in the weights of the lateral vaginae, with treated animals showing no evidence of oestrogenic stimulation. The remaining three control and three treated animals were monitored for approximately 2 years. The long-term contraceptive effects of a single $5 \mathbf{~ m g}$ deslorelin implant lasted for just under one year. These results indicate that slow release deslorelin implants inhibit follicular development in the female tammar wallaby for extended periods of time and may have potential application in reproductive management of captive marsupials in the kangaroo family.
\end{abstract}

Reproduction (2004) 127 265-273

\section{Introduction}

In recent years there has been increasing attention given to the challenges of managing over-abundant marsupial populations in Australia, in particular the large macropodids (kangaroos and wallabies) and the koala. Lethal control techniques, such as shooting and poisoning, are now facing increasing public opposition. Reducing population size over time by artificially reducing the fertility of individuals within the population (fertility control) has been proposed as an alternative method of population control (Bomford 1990). This has resulted in research and development of new technologies to inhibit marsupial reproduction (Nave et al. 2000, 2002).

Gonadotrophin releasing hormone $(\mathrm{GnRH})$ agonist treatment has been shown to temporarily suppress ovarian cycles in dogs (Lacoste et al. 1989, Trigg et al. 2001), ewes (McNeilly \& Fraser 1987), marmoset monkeys (Lunn et al. 1992), stumptailed macaques (Fraser \& Sandow 1985) and women (Fraser et al. 1990). In these species, suppression of ovarian cycles is characterised by an inhibition of follicular development, with a resultant decline in the concentrations of oestradiol and progesterone and an inhibition of oestrus. In ewes (McNeilly \& Fraser 1987), heifers (Mattos et al. 2001) and women (Bider et al. 1989) ovarian follicular development is arrested at the early antral stages of development, as evidenced by the absence of large follicles in the ovaries. In addition, the luteinising hormone (LH) surge mechanism is inhibited, as is ovulation.

Treatment with long-acting implant formulations containing the GnRH agonist, deslorelin, has resulted in long-term inhibition of reproductive function in cats (Munson et al. 2001), dogs (Trigg et al. 2001), heifers (D'Occhio et al. 1996, 2000) and other wildlife species (Bertschinger et al. 2001, 2002). The longevity of these $\mathrm{GnRH}$ agonist formulations increases their potential application in the management of over-abundant wild and captive marsupial populations.

The tammar wallaby is well established as a model marsupial species for the study of reproduction and endocrinology (Tyndale-Biscoe \& Renfree 1987, Tyndale-Biscoe \& 
Janssens 1988). It is a monovular, polyoestrous species, with ovulation usually occurring in the alternate ovary in each successive cycle (Tyndale-Biscoe \& Renfree 1987). Breeding is highly seasonal, with the majority of births occurring in a synchronised fashion in late January and early February (Renfree \& Tyndale-Biscoe 1973, Sadleir \& Tyndale-Biscoe 1977, Hinds \& den Ottolander 1983). Females mate within 1-2 h of giving birth (Rudd 1994) and the conceptus grows to the stage of a 100-cell blastocyst before entering embryonic diapause. In the wild, these blastocysts usually remain in diapause for 11 months (Berger 1966, Renfree \& Tyndale-Biscoe 1973, Flint \& Renfree 1982). From the summer solstice until the winter solstice diapause is maintained by the suckling stimulus of the young in the pouch (lactational quiescence) (TyndaleBiscoe et al. 1974). If a young is lost or removed during this period of decreasing day length the quiescent corpus luteum (CL) and blastocyst will reactivate (Renfree 1979), and birth and a new post-partum oestrus will occur approximately $26.5 \pm 0.4$ days later (Merchant, 1979, Renfree et al. 1989). If the young is removed or lost during the period of increasing day length, reactivation of the $C L$ and blastocyst is inhibited by photoperiod (seasonal quiescence). Development will not resume until after the summer solstice (Tyndale-Biscoe et al. 1974).

The follicular phase in the tammar begins around midpregnancy. Graafian follicles are evident from day 23 after removal of pouch young (RPY) and reach their maximum size at the time of post-partum oestrus (Harder et al. 1984). Behavioural oestrus coincides with a post-partum peak of oestradiol in the peripheral circulation (Shaw \& Renfree 1984) and in the vein draining the ovary with the Graafian follicle (Harder et al. 1984). The oestradiol peak is followed $5-8 \mathrm{~h}$ later by a preovulatory $\mathrm{LH}$ surge (Tyndale-Biscoe et al. 1983, Harder et al. 1985, Fletcher \& Renfree 1988) with ovulation occurring approximately $24 \mathrm{~h}$ after the LH surge (Harder et al. 1985) or $40 \mathrm{~h}$ after birth (Renfree \& Lewis 1996). The period of oestrus and ovulation in the tammar appears to be regulated by both oestradiol and LH, as in eutherians (Hinds et al. 1996). The later stages of follicular development appear to be pituitary-dependent. Hypophysectomy results in an absence of the largest (type 8) follicles within three weeks (Hearn 1975, Panyaniti et al. 1985) and passive immunisation against $\mathrm{GnRH}$ inhibits the late antral stages of follicular development (Short et al. 1985). However, the tammar $\mathrm{CL}$ is not dependent on gonadotrophins for reactivation or the maintenance of pregnancy, as gestation is unaffected by hypophysectomy (Hearn 1974) or passive immunisation against GnRH (Short et al. 1985).

This study investigated the efficacy of using slow release implants containing the GnRH agonist, deslorelin, to inhibit reproduction in the female tammar wallaby. The specific aims were to investigate the effects of deslorelin treatment at the time of RPY on subsequent follicular growth, birth and post-partum oestrus in animals presumed to be carrying a dormant blastocyst. No attempts were made to measure the hormone concentrations in this study because frequent sampling around the period of parturition, post-partum oestrus and ovulation probably interferes with these processes (Fletcher et al. 1990).

\section{Materials and Methods}

\section{Animals}

The tammar wallabies used in this experiment were captured on Kangaroo Island, South Australia and transferred to the Macquarie University Fauna Park facility in August 1999. For the duration of the experiment they were held in a large outdoor pen, with a ratio of 3 males to 16 females. The animals were fed specially formulated 'kangaroo' cereal pellets (Gordon Specialty Stock Feed, Carlingford, Sydney, Australia) and lucerne hay with water available ad libitum. All females selected for this experiment were over two years of age with an average weight of $5.08 \pm 0.16 \mathrm{~kg}$. All were nursing pouch young $(P Y)$ and were presumed to be carrying a dormant blastocyst from a post-partum mating. Males were used for breeding purposes only and were not subject to any form of treatment. The Macquarie University Animal Ethics Committee approved all experimental work (approval number 99009) and the animal handling and husbandry was conducted in accordance with National Health and Medical Research Council of Australia guidelines (1990).

\section{Experimental design}

Sixteen female tammar wallabies were synchronised by RPY on 1 March 2000 (day 0). At the time of RPY the animals were randomly assigned to the treatment $(n=8)$ or the control group $(n=8)$. Treated animals received a $5 \mathrm{mg}$ deslorelin implant and control animals received a placebo implant. Animals were caught once every 7 days to accustom them to catching and handling procedures. From day 25 after RPY the animals were caught daily and their pouches examined for the presence of a copulatory plug, which usually remains in position for at least $24 \mathrm{~h}$ post coitum (Sutherland et al. 1980). Female tammars usually mate $1-2 \mathrm{~h}$ post-partum (Rudd 1994), but mating is sometimes delayed until $8 \mathrm{~h}$ (Tyndale-Biscoe et al. 1983) or even $18 \mathrm{~h}$ (Harder et al. 1985) after birth when animals are frequently sampled during the birth and post-partum period. The first five animals from each group to give birth and/or mate were killed at the first sign of a copulatory plug. If they had not mated within $24 \mathrm{~h}$ of the first observation of a neonate (i.e. within $24-48 \mathrm{~h}$ of birth), they were killed at this time.

\section{Sample collection}

Five animals from each group were killed by an intravenous injection of pentobarbitone sodium $(1 \mathrm{ml} / 2 \mathrm{~kg}$; Lethabarb, Virbac Pty. Ltd, Peakhurst, NSW, Australia). The reproductive tracts were dissected out and examined. 
The ovaries were checked for the presence of follicles or recent ovulations, before weighing (Sartorius electronic analytical balance, Max $=110 \mathrm{~g}, \mathrm{~d}=0.1 \mathrm{mg}, 1601 \mathrm{MP} 8$ ) and fixing in $10 \%$ neutral buffered formalin. The ovaries were embedded in paraffin wax, serially sectioned at $7 \mu \mathrm{m}$ and stained with haematoxylin and eosin for subsequent histological examination and confirmation of the gross observations at the time of post-mortem. The uteri were examined for the presence of fetuses or evidence of recent pregnancy and then weighed individually. The lateral vaginae were dissected free of adjacent connective tissue and weighed to give an index of the animal's oestrogenic status (Short et al. 1985).

\section{Long-term monitoring}

The remaining three control and three treated animals were monitored once every 4-8 weeks from April 2000 until June 2002 to determine the duration of the contraceptive effects and the reversibility of treatment. All PY were removed and their age determined by measuring the head length and calculating the age from tammar wallaby PY growth tables (Poole et al. 1991). Following the resumption of reproductive activity in two of the treated animals, all of the three previously treated animals were re-treated on 15 March 2001 with a double dose of deslorelin (10 mg deslorelin).

\section{GnRH agonist implant}

The GnRH agonist, deslorelin (D-Trp ${ }^{6}$-Pro ${ }^{9}$-des-gly ${ }^{10}$ $\mathrm{GnRH}$ ethylamide), was formulated into implants that contained $5 \mathrm{mg}$ deslorelin (Batch DR027A; Peptech Animal Health Pty. Ltd, North Ryde, NSW, Australia) as previously described (Trigg et al. 2001). In a real time dissolution system the release of deslorelin was $>1$ $\mu \mathrm{g} /$ day for periods of approximately 1 year (Trigg et al. 2001). The in vivo release rate in tammar wallabies has not been determined. Implants were placed s.c. between the shoulder blades using a single-use commercial implanting device sterilised by e-beam radiation. The injection site was then sealed with a veterinary tissue adhesive (Vetbond, 3M Animal Care Products, St Paul, MN, USA). The dimensions of a $5 \mathrm{mg}$ deslorelin implant were $2.3 \mathrm{~mm}$ in width and $12.5 \mathrm{~mm}$ in length.

\section{Statistical analyses}

Comparisons of the weight of reproductive tract components were analysed using two-sample $t$-tests. Comparisons of the number of pouch young and copulatory plugs for each group were made using the crosstabs chi-square Fisher's Exact test feature of SPSS 1996. Data are presented as arithmetic means \pm S.E.M. Results were reported as significant at $P=0.05$.

\section{Results}

\section{Timing of birth}

All control and treated females were synchronised by RPY at the time of implant administration, thus demonstrating their fertility at the start of the experiment. Following deslorelin treatment there was no significant difference in the number of animals giving birth from each group $\left(\chi^{2}=1.067\right.$, degrees of freedom (d.f.) $\left.=1, P>0.05\right)$. Six (out of eight) control animals gave birth between days 25 and 27, and four (out of eight) treated animals gave birth, all on day 27 (Table 1). In one treated animal (number 691) the newborn young was found dead in the pouch.

Table 1 Incidence of birth and mating in control and deslorelin-treated female tammar wallabies between days 25 and 30 after removal of pouch young, and structures present in the ovaries at post-mortem.

\begin{tabular}{|c|c|c|c|c|c|}
\hline & \multirow[b]{2}{*}{ Birth } & \multirow[b]{2}{*}{ Copulatory plug } & \multirow[b]{2}{*}{ Post-mortem } & \multicolumn{2}{|c|}{ Structures present in ovary } \\
\hline & & & & Parturient side & Non-parturient side \\
\hline \multicolumn{6}{|l|}{ Control } \\
\hline 692 & Day 27 & Day 27 & Day 27 & Old CL & Preovulatory follicle \\
\hline 1BE0558T & Day 27 & Day 27 & Day 27 & Old CL & Preovulatory follicle \\
\hline 1E710E8T & Day 27 & Day 27 & Day 27 & Old CL & Preovulatory follicle \\
\hline 537 & Day 27 & Day 28 & Day 28 & Old CL & Preovulatory follicle \\
\hline 548 & Day 26 & Day 26 & Day 26 & Old CL & Preovulatory follicle \\
\hline 686 & Day 27 & No & NA & & \\
\hline 1E71BB2T & No & Day 30 & NA & & \\
\hline 543 & No & No & NA & & \\
\hline \multicolumn{6}{|l|}{ Treated } \\
\hline 683 & Day 27 & No & Day 28 & Old CL & No large follicles or recent ovulation \\
\hline 1BE05E1T & Day 27 & No & Day 28 & Old CL & No large follicles or recent ovulation \\
\hline 691 & Day $27 *$ & No & Day 28 & Old CL & No large follicles or recent ovulation \\
\hline 695 & Day 27 & No & Day 28 & Old CL & No large follicles or recent ovulation \\
\hline 532 & No & Day 26 & Day 26 & Old CL & Preovulatory follicle \\
\hline 689 & No & No & NA & & \\
\hline 20166Е3T & No & No & NA & & \\
\hline 542 & No & No & NA & & \\
\hline
\end{tabular}

NA, not applicable; *, young found dead in pouch. 
Copulatory plugs were observed in a significantly greater number of control than treated females between day 25 and day 30 (control, 6/8; treated, $1 / 8 ; \chi^{2}=6.349$, d.f. $=1, P<0.05)$. One treated female mated on day 26 , but no PY was observed in the pouch. Examination of the reproductive tract of this female suggested that she was recently gravid, as one uterus was significantly larger than the other. Of the six control animals that gave birth, copulatory plugs were observed in all but one animal. This animal was not killed and following RPY a second young was born 27 days later suggesting that a post-partum mating had occurred, but this was not evident from physical examination.

\section{Effects on the reproductive tract}

At the time of post-mortem there were marked gross morphological differences between the reproductive tracts of control and deslorelin-treated animals (Fig. 1a and b). This was also reflected in the weights of the various components of the reproductive tract. The vaginal complex (median and lateral vaginae) of control animals was significantly heavier than treated animals (control, $23.10 \pm 3.27 \mathrm{~g}$; treated, $7.28 \pm 2.70 \mathrm{~g} ; P<0.01)$. There was a tendency for both uteri to be heavier in control than treated animals, but this difference was not significant (parturient uterus: control, $1.78 \pm 0.41 \mathrm{~g}$, treated, $1.04 \pm 0.11 \mathrm{~g}$; non-parturient uterus: control $1.04 \pm 0.40 \mathrm{~g}$, treated $0.35 \pm 0.07 \mathrm{~g}$; $P>0.05$ ).

In all five control animals there was a regressing $\mathrm{CL}$ from the recent pregnancy in one ovary (Fig. 2a) and a large preovulatory follicle (diameter $>3.5 \mathrm{~mm}$ ) in the contralateral ovary (Fig. 2b). In contrast, deslorelin-treated animals showed a normal regressing $\mathrm{CL}$ in one ovary (Fig. 2c) and early antral stage follicles (Fig. 2d) in the second ovary. A large pre-ovulatory follicle was only observed in one deslorelin-treated animal (Fig. 2e and f), and this was the same animal that mated within the $24 \mathrm{~h}$ preceding post-mortem on day 26 . In the remaining four treated animals, there was no evidence of preovulatory follicles or recent ovulations in either ovary.

The ovaries of control animals tended to be heavier than the ovaries of treated animals. For the ovary with the regressing $\mathrm{CL}$, this difference was not significant (control, $201 \pm 37 \mathrm{mg}$; treated, $142 \pm 17 \mathrm{mg} ; P>0.05)$. For the contralateral ovary (the ovary associated with the non-parturient uterus) there was a significant difference when animal 532 was excluded on the basis that it did not respond to the treatment in the same fashion as the remainder of the population and was therefore an outlier. The ovary with the large preovulatory follicle in control animals was on average double the weight of treated animals without large follicles (control, $229 \pm 41 \mathrm{mg}$; treated, $111 \pm 22 \mathrm{mg} ; P<0.05)$.

\section{Long-term reproductive success}

After the period of daily capture, the remaining six females were monitored at less regular intervals. One treated animal (number 689) gave birth early in May 2000 (Table 2), but did not give birth again before administration of a second deslorelin implant. The remaining two treated females gave birth early the following breeding season, 340 and 359 days after the implant was administered (Table 2). After treatment with a further $10 \mathrm{mg}$ deslorelin, none of the treated animals gave birth for the

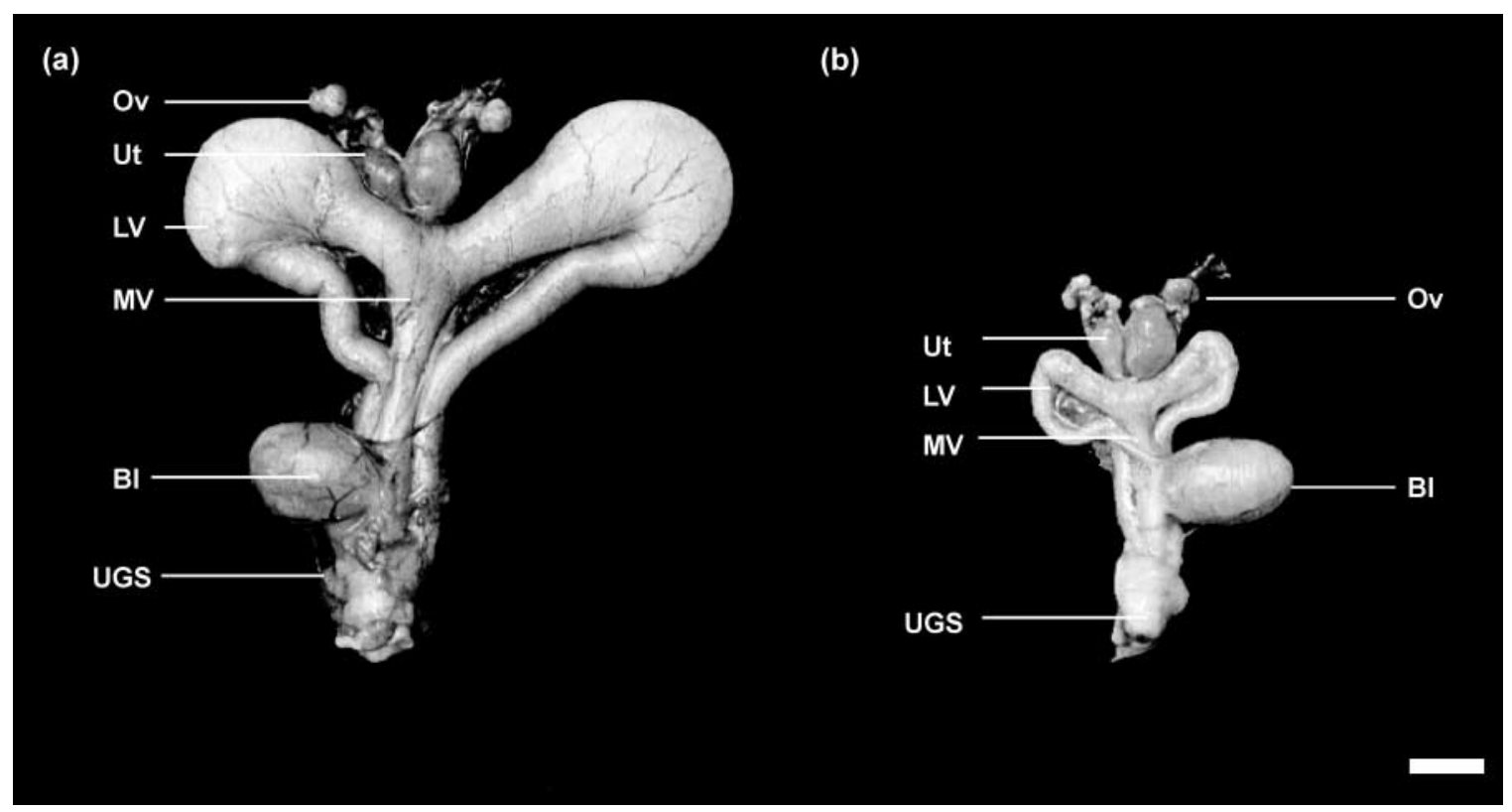

Figure 1 Ventral view of the reproductive tracts of (a) control animal no. 537 and (b) deslorelin-treated animal no. 691 within $0-48 \mathrm{~h}$ of birth and/or post-partum mating. In both animals the parturient uterus is on the right hand side of the photograph. Scale bar $=10 \mathrm{~mm}$. Ov, ovary; Ut, uterus; LV, lateral vagina; MV, median vagina; Bl, bladder; UGS, urogenital sinus. 

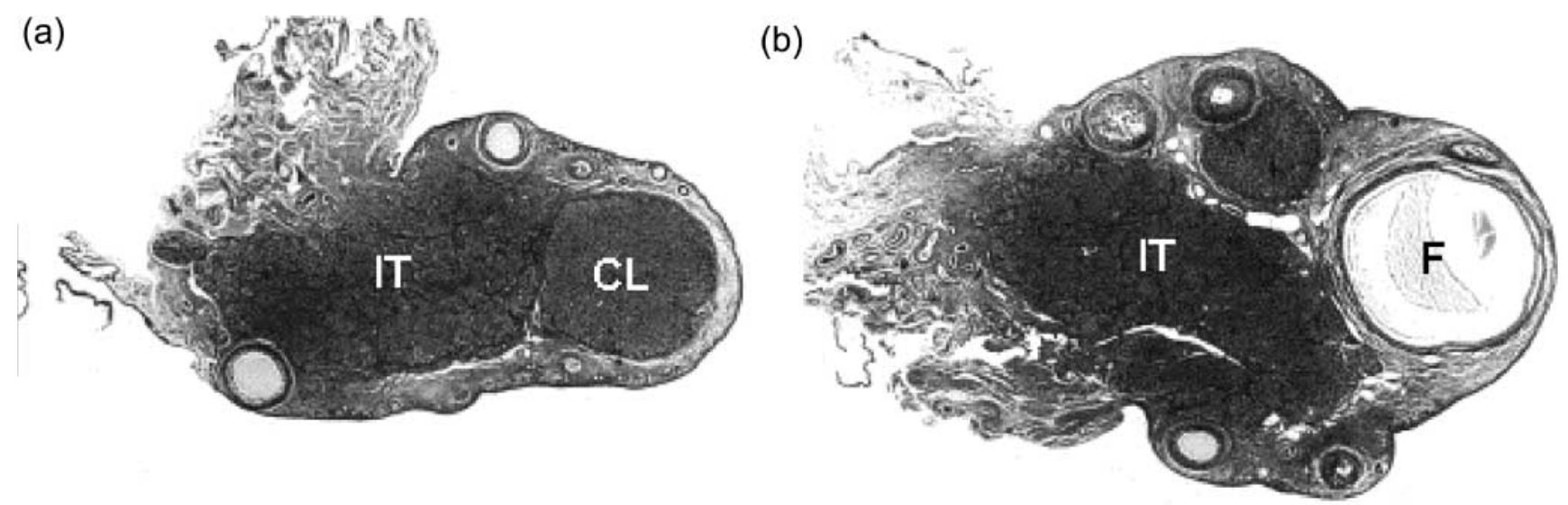

(c)

(d)
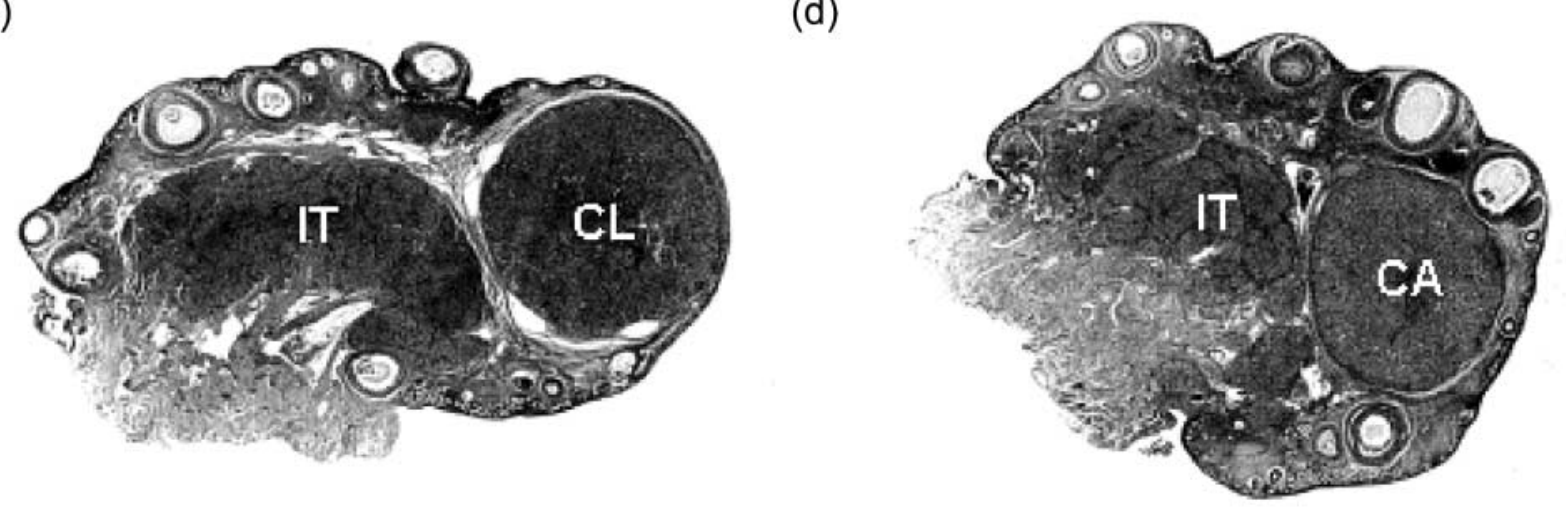

(e)

(f)
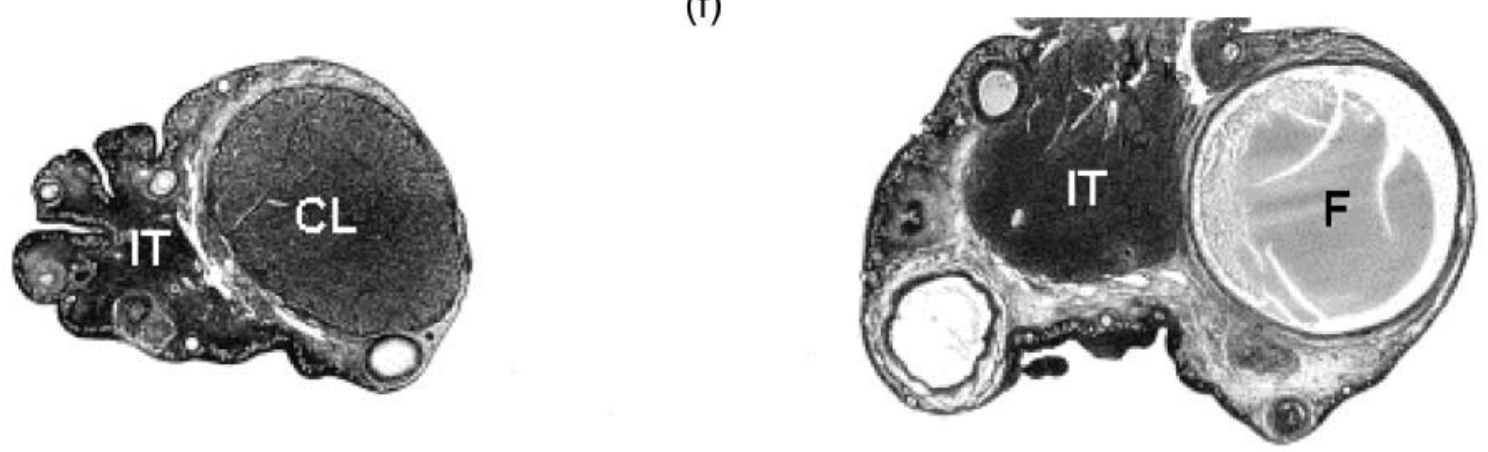

Figure 2 Ovarian histology of one control and two deslorelin-treated wallabies. (a and b) Control animal 692 showing (a) the regressing $\mathrm{CL}$ of the recent pregnancy and (b) a large preovulatory follicle (F); ( $\mathrm{c}$ and d) treated animal 695 showing (c) the regressing $\mathrm{CL}$ of the recent pregnancy and (d) the absence of any large preovulatory follicles; (e and f) treated animal 532 which mated on day 26 showing (e) the regressing $\mathrm{CL}$ of the recent pregnancy and $(\mathrm{f})$ a large preovulatory follicle. Scale bar $=1 \mathrm{~mm}$. CA, corpus albicans; IT, interstitial tissue.

remainder of the 2001 breeding season or during the 2002 breeding season, a period of 464 days. Two of the control animals bred within 60 days of administration of a placebo implant (Table 2). The remaining animal died within 3 months of placebo implant administration and did not breed during this time.

\section{Discussion}

Treatment with the GnRH agonist, deslorelin, at the time of RPY did not appear to inhibit the reactivation of a quiescent blastocyst and subsequent birth, but successfully inhibited follicular development and post-partum oestrus in $4 / 5$ animals. Moreover, these contraceptive effects can 
Table 2 Duration of contraception in long-term deslorelin-treated female tammar wallabies, compared with the reproductive success in control female tammars.

\begin{tabular}{|c|c|c|c|c|}
\hline Animal no. & Treatment & Treatment date & Date of birth & Days post-treatment \\
\hline \multirow[t]{2}{*}{689} & Deslorelin (5 mg) & 01-Mar-00 & 01-Mar-00 & 61 \\
\hline & Deslorelin $(10 \mathrm{mg})$ & 15-Mar-01 & - & $>464^{\mathrm{a}}$ \\
\hline \multirow[t]{2}{*}{ 20166Е3T } & Deslorelin (5 mg) & 01-Mar-00 & 04-Feb-01 & 340 \\
\hline & Deslorelin $(10 \mathrm{mg})$ & 15-Mar-01 & - & $>464^{\mathrm{a}}$ \\
\hline \multirow[t]{2}{*}{542} & Deslorelin $(5 \mathrm{mg})$ & 01-Mar-00 & 23-Feb-01 & 359 \\
\hline & Deslorelin (10 mg) & 15-Mar-01 & - & $>464^{\mathrm{a}}$ \\
\hline \multirow[t]{2}{*}{ 1E71BB2T } & Placebo & 01-Mar-00 & 28-Apr-00 & 58 \\
\hline & Placebo & 15-Mar-01 & 02-May-01 & 48 \\
\hline \multirow[t]{2}{*}{686} & Placebo & 01-Mar-00 & 28-Mar-00 & 27 \\
\hline & Placebo & 15-Mar-01 & 11-May-01 & 57 \\
\hline \multirow[t]{2}{*}{543} & Placebo & 01-Mar-00 & - & $-b$ \\
\hline & Placebo & 15-Mar-01 & - & $-^{\mathrm{c}}$ \\
\hline
\end{tabular}

${ }^{\mathrm{a}}$, Duration of contraception to date at the end of the 2002 breeding section; ${ }^{\mathrm{b}}$, no births detected following treatment; ${ }^{\mathrm{c}}$, animal died on 28 May 2001.

be maintained for periods of approximately 1 year. This demonstrates the potential of deslorelin implants for controlling reproduction in tammar wallabies.

The inhibition of follicular development and oestrus during deslorelin treatment in the present study was consistent with findings from other species. Short-term treatment of heifers with deslorelin resulted in a decline in the numbers of class $2(6$ to $9 \mathrm{~mm})$ and class $3(>9 \mathrm{~mm})$ follicles, although the number of class $1(<6 \mathrm{~mm})$ follicles was not affected (Mattos et al. 2001). Similarly, ewes treated with the GnRH agonist, buserelin, had no follicles $>2.5 \mathrm{~mm}$ in diameter (McNeilly \& Fraser 1987). In both species, inhibition of follicular development was accompanied by a decline in peripheral plasma folliclestimulating hormone ( $\mathrm{FSH}$ ) concentrations and an absence of pulsatile release of $\mathrm{LH}$, suggesting that gonadotrophin support is not required for the maintenance of smaller follicles, but is required for the development of larger follicles (McNeilly \& Fraser 1987, Gong et al. 1996). Although the concentrations of FSH and $\mathrm{LH}$ were not measured in the present study, the absence of follicular development suggests that there was inadequate gonadotrophic support for normal follicular development. A similar attenuation in the growth of follicles was reported in female tammars following passive immunisation against $\mathrm{GnRH}$ (Short et al. 1985) and hypophysectomy (Hearn 1974, Panyaniti et al. 1985).

Studies in heifers have demonstrated that suppression of follicular growth was caused by decreased gonadotrophic support rather than a direct action of GnRH agonist on the ovaries (D'Occhio et al. 2000). In addition, no binding sites for $\mathrm{GnRH}$ or $\mathrm{GnRH}$ agonists have been identified in bovine ovarian tissues (Gong et al. 1996). The GnRH receptor transcript has recently been detected in ovarian tissue of tammar wallabies (Cheung \& Hearn 2002). Therefore, it is possible that deslorelin is having a direct effect at the level of the ovaries as well as at the level of the pituitary, as occurs during $\mathrm{GnRH}$ agonist treatment in the rat (Janssens et al. 2000). It has been hypothesised that $\mathrm{GnRH}$ agonists may directly affect ovarian steroidogenesis in the rat via ovarian $\mathrm{GnRH}$ receptors which are part of a local autoregulatory system (Roth et al. 2001). The role of ovarian $\mathrm{GnRH}$ receptors in the tammar wallaby deserves further investigation.

In deslorelin-treated tammars, oestradiol concentrations would presumably have remained at basal levels, as is the case in heifers (Mattos et al. 2001) and mice (Bokser et al. 1989), as the preovulatory follicle is known to be the source of the high oestradiol concentrations coincident with behavioural oestrus following the pregnant and oestrous cycle (Harder et al. 1985). The inhibition of oestrus and the absence of an oestrogenic response in the vaginae further support this hypothesis.

Deslorelin treatment did not affect normal gestation or parturition in $60 \%(3 / 5)$ of animals. This is in accordance with the results of Short et al. (1985) who showed that passive immunisation against GnRH does not inhibit gestation or progesterone secretion after RPY. After hypophysectomy, pregnancies proceed to term but parturition does not occur (Hearn 1974), thereby demonstrating that gonadotrophin secretion is not required for successful luteal reactivation or gestation.

In the control group, parturition successfully occurred and live young were observed in the pouch of all five of the animals in which reproductive tracts were analysed. In the treated group, live young were observed in only three animals. Whether the loss of two out of five young in treated animals compared with none out of five in control animals is a direct result of deslorelin treatment requires further investigation. The three treated animals in which live young were observed successfully suckled these young for periods of between 24 and $48 \mathrm{~h}$ suggesting that the early phase of lactation was not affected.

The maintenance of follicular development and subsequent occurrence of oestrus in one treated animal demonstrates that there are individual differences in the response to deslorelin treatment, and highlights the possibility that an unknown proportion of the population may not be responsive to the contraceptive effects of deslorelin treatment. The occurrence of oestrus during deslorelin 
treatment has also been noted in individual heifers. Oestrus in these cows indicated that ovarian follicular growth and oestrogen production continued during deslorelin treatment. The higher levels of oestrogen were able to stimulate oestrus but were presumably insufficient to stimulate a preovulatory LH surge and ovulation, because there was no increase in plasma progesterone concentrations after oestrus ( $\mathrm{D}^{\prime}$ Occhio et al. 1996). It has been demonstrated that treated heifers will not respond to $\mathrm{GnRH}$ stimulus with an LH surge, which could explain this presumed lack of ovulation (Bergfeld et al. 1996). The current understanding is that cows treated with $\mathrm{GnRH}$ agonist can show some growth of ovarian follicles, but ovulation does not occur, either because follicle maturation is not complete or the gonadotroph cells in the pituitary become insensitive to natural $\mathrm{GnRH}$ ( $\mathrm{D}^{\prime}$ Occhio et al. 1996). In the present study, the 'non-responder' was killed before the time of ovulation so we do not know whether ovulation would have occurred normally. It is possible that although there was obviously sufficient gonadotrophic support for follicular development, the pituitary may have been desensitised to the extent that this animal would have failed to generate a preovulatory $\mathrm{LH}$ surge, resulting in a failure to ovulate. In a study by Lunn et al. (1992), one buserelin-treated marmoset monkey (out of six) appeared to continue to have ovarian cycles based on plasma oestradiol and progesterone concentrations. However, this animal failed to respond to a $\mathrm{GnRH}$ challenge 3 weeks after buserelin implant insertion, suggesting that the pituitary was desensitised.

The long-term effects of deslorelin treatment were monitored in the three remaining treated animals. One treated female (689) gave birth within 2 months of deslorelin administration, suggesting that follicular development and ovulation had not been inhibited in this animal. There are two possible explanations for the continued reproductive activity in this animal. The dose administered $(5 \mathrm{mg}$ ) may have been insufficient to desensitise the pituitary and significantly reduce gonadotrophin secretion within one oestrous/pregnant cycle, or this individual may be resistant to the contraceptive effects of deslorelin treatment. After removal of the pouch young there was no evidence of reproductive activity in this female for 10 months. In addition, after administration of a higher dose the animal did not breed for a period of 16 months (experiment continuing at time of writing). This suggests that this animal is not resistant to the contraceptive effects of deslorelin, but there may have been insufficient time or dose for downregulation to occur. Ineffective pituitary suppression has been suggested as a potential reason for higher conception rates in heifers treated with low doses of deslorelin ( $D^{\prime}$ Occhio et al. 2000). The remaining two treated animals first bred approximately one year after treatment with $5 \mathrm{mg}$ deslorelin. After administration of $10 \mathrm{mg}$ deslorelin, none of the treated animals bred during the following 16 months. The use of higher doses of deslorelin has been associated with longer contraceptive duration in heifers
(D'Occhio et al. 2000) and male dogs (Trigg et al. 2001). The results from this small tammar trial suggest that a similar dose-response relationship may exist for the tammar. However, these results should be viewed cautiously as the first and second dosages were from different batches of deslorelin implants and the long-term effects of previous treatment on the pituitary in tammar wallabies are unknown.

In summary, deslorelin implants were successful at inhibiting follicular development and mating in the tammar wallaby. The long-term contraceptive effects lasted for approximately one year. This demonstrates the potential of these implants to reversibly inhibit reproduction in macropodid marsupials. The successful reactivation of quiescent blastocysts and the probable maintenance of lactation following their birth may limit the usefulness of this contraceptive in the majority of macropodid species which mate post-partum. However, post-partum mating is not a feature of the eastern grey kangaroo, M. giganteus, or the koala, Phascolarctos cinereus, which are two of the species presenting widespread management challenges. Therefore, deslorelin may be an efficacious fertility control option for these species and further trials are warranted. The relationship between dose and duration of action should be investigated in an attempt to gain longer contraceptive duration. Trials are also required in a larger group of animals to gain a more accurate estimation of the contraceptive success rate in the tammar wallaby, and the basis for any non-response.

\section{Acknowledgements}

This work was supported by the Australian Research Council Strategic Partnerships with Industry Research and Training grant scheme. C A H was the recipient of an Australian Postgraduate Award. The authors thank R Claassens and A Mouland for assistance with the handling and care of the animals in this study, J Norman and R Oldfield for assistance with the microscopy and photomicrography and Peptech Animal Health Pty. Ltd for the generous supply of deslorelin implants.

\section{References}

Berger PJ 1966 Eleven-month 'embryonic diapause' in a marsupial. Nature 211 435-436.

Bergfeld EG, D'Occhio MJ \& Kinder JE 1996 Pituitary function, ovarian follicular growth, and plasma concentrations of 17 beta-estradiol and progesterone in prepubertal heifers during and after treatment with the luteinizing hormone-releasing hormone agonist deslorelin. Biology of Reproduction 54 776-782.

Bertschinger HJ, Asa CS, Calle PP, Long JA, Bauman K, DeMatteo K Jochle W, Trigg TE \& Human A 2001 Control of reproduction and sex related behaviour in exotic wild carnivores with the $\mathrm{GnRH}$ analogue deslorelin: preliminary observations. Journal of Reproduction and Fertility Supplement 57 275-283.

Bertschinger HJ, Trigg T, Jochle W \& Human A 2002 Induction of contraception in some African wild carnivores by downregulation of $\mathrm{LH}$ and $\mathrm{FSH}$ secretion using the $\mathrm{GnRH}$ analogue deslorelin. Reproduction Supplement 60 41-52.

Bider D, Ben-Rafael Z, Shalev J, Goldenberg M, Mashiach S \& Blankstein J 1989 Pituitary and ovarian suppression rate after high 
dosage of gonadotropin-releasing hormone agonist. Fertility and Sterility 51 578-581.

Bokser L, Zalatani A \& Schalley AV 1989 Inhibition of pituitarygonadal axis in mice by long-term administration of D-Trp-6LHRH microcapsules. Journal of Reproduction and Fertility 85 569-574.

Bomford M 1990 A role for fertility control in wildlife management? Department of Primary Industries, Bureau of Rural Resources Bulletin No. 7, pp 50. Canberra: Australian Government Publishing Service.

Cheung TC \& Hearn JP 2002 Molecular cloning and tissue expression of the gonadotrophin-releasing hormone receptor in the tammar wallaby (Macropus eugenii). Reproduction, Fertility and Development 14 157-164.

D'Occhio MJ, Aspden WJ \& Whyte TR 1996 Controlled, reversible suppression of estrous cycles in beef heifers and cows using agonists of gonadotrophin-releasing hormone. Journal of Animal Science 74 218-225.

D'Occhio MJ, Fordyce G, Whyte TR, Aspden WJ \& Trigg TE 2000 Reproductive responses of cattle to GnRH agonists. Animal Reproduction Science 60-61 433-442.

Fletcher TP \& Renfree MB 1988 Effects of corpus luteum removal on progesterone, estradiol-17 beta and LH in early pregnancy of the tammar wallaby, Macropus eugenii. Journal of Reproduction and Fertility 83 185-191.

Fletcher TP, Shaw G \& Renfree MB 1990 Effects of bromocriptine at parturition in the tammar wallaby, Macropus eugenii. Reproduction, Fertility and Development 2 79-88.

Flint AP \& Renfree MB 1982 Oestradiol-17 beta in the blood during seasonal reactivation of the diapausing blastocyst in a wild population of tammar wallabies. Journal of Endocrinology 95 293-300.

Fraser HM \& Sandow J 1985 Suppression of follicular maturation by infusion of a luteinizing hormone-releasing hormone agonist starting during the late luteal phase in the stumptailed macaque monkey. Journal of Clinical Endocrinology and Metabolism 60 579-584.

Fraser HM, Sandow J, Cowen GM, Lumsden MA, Haining R \& Smith SK 1990 Long-term suppression of ovarian function by a luteinizing-hormone releasing hormone agonist implant in patients with endometriosis. Fertility and Sterility 53 61-68.

Gong JG, Campbell BK, Bramley TA, Gutierrez CG, Peters AR \& Webb R 1996 Suppression in the secretion of follicle-stimulating hormone and luteinizing hormone, and ovarian follicle development in heifers continuously infused with a gonadotropin-releasing hormone agonist. Biology of Reproduction 55 68-74.

Harder JD, Hinds LA, Horn CA \& Tyndale-Biscoe CH 1984 Oestradiol in follicular fluid and in utero-ovarian venous and peripheral plasma during parturition and postpartum oestrus in the tammar. Macropus eugenii. Journal of Reproduction and Fertility $\mathbf{7 2}$ 551-558.

Harder JD, Hinds LA, Horn CA \& Tyndale-Biscoe CH 1985 Effects of removal in late pregnancy of the corpus luteum, Graafian follicle or ovaries on plasma progesterone, oestradiol, $\mathrm{LH}$, parturition and post-partum oestrus in the tammar wallaby, Macropus eugenii. Journal of Reproduction and Fertility 75 449-459.

Hearn JP 1974 The pituitary gland and implantation in the tammar wallaby, Macropus eugenii. Journal of Reproduction and Fertility $39235-241$.

Hearn JP 1975 Hypophysectomy of the tammar wallaby, Macropus eugenii: surgical approach and general effects. Journal of Endocrinology 64 403-416.

Hinds LA \& den Ottolander RC 1983 Effect of changing photoperiod on peripheral plasma prolactin and progesterone concentrations in the tammar wallaby (Macropus eugenii). Journal of Reproduction and Fertility $69631-639$.

Hinds LA, Fletcher TP \& Rodger JC 1996 Hormones of oestrus and ovulation and their manipulation in marsupials. Reproduction, Fertility and Development 8 661-672.
Janssens RMJ, Brus L, Cahill DJ, Huirne JAF, Schoemaker J \& Lambalk CBL 2000 Direct ovarian effects and safety aspects of $\mathrm{GnRH}$ agonists and antagonists. Human Reproduction Update 6 505-518.

Lacoste D, Dube D, Trudel C, Belanger A \& Labrie F 1989 Normal gonadal functions and fertility after 23 months of treatment of prepubertal male and female dogs with the GnRH agonist [D-Trp6, des-Gly- $\left.\mathrm{NH}_{2}(10)\right] \mathrm{GnRH}$ ethylamide. Journal of Andrology $\mathbf{1 0}$ 456-465.

Lunn SF, Cowen GM, Morris KD \& Fraser HM 1992 Influence of the gonad on the degree of suppression induced by an LHRH agonist implant in the marmoset monkey. Journal of Endocrinology 132 217-224.

McNeilly AS \& Fraser HM 1987 Effect of gonadotrophin-releasing hormone agonist-induced suppression of $\mathrm{LH}$ and FSH on follicle growth and corpus luteum function in the ewe. Journal of Endocrinology 115 273-282.

Mattos R, Orlandi C, Williams J, Staples CR, Trigg T \& Thatcher WW 2001 Effect of an implant containing the GnRH agonist deslorelin on secretion of $\mathrm{LH}$, ovarian activity and milk yield of postpartum dairy cows. Theriogenology 56 371-386.

Merchant JC 1979 The effect of pregnancy on the interval between one oestrus and the next in the tammar wallaby, Macropus eugenii. Journal of Reproduction and Fertility 56 459-463.

Munson L, Bauman CS, Asa CS, Jochle W \& Trigg TE 2001 Efficacy of the $\mathrm{GnRH}$ analogue deslorelin for suppression of oestrous cycles in cats. Journal of Reproduction and Fertility Supplement 57 269-273.

National Health and Medical Research Council 1990 In Australian Code of Practice for the Care and Use of Animals for Scientific Purposes. Canberra, ACT: Australian Government Publishing Service.

Nave CD, Shaw G, Short RV \& Renfree MB 2000 Contraceptive effects of levonorgestrel implants in a marsupial. Reproduction, Fertility and Development 12 81-86.

Nave CD, Coulson G, Poiani A, Shaw G \& Renfree MB 2002 Fertility control in the eastern grey kangaroo using levonorgestrel implants. Journal of Wildlife Management 66 470-477.

Panyaniti W, Carpenter SM \& Tyndale-Biscoe CH 1985 Effects of hypophysectomy on folliculogenesis in the tammar Macropus eugenii (Marsupialia: Macropodidae). Australian Journal of Zoology 33 303-311.

Poole WE, Simms NG, Wood JT \& Lubulwa M 1991 Tables for age determination of the Kangaroo Island wallaby (tammar), Macropus eugenii, from body measurements. Technical Memorandum no 32, pp 37. Canberra: CSIRO Division of Wildlife and Ecology.

Renfree MB 1979 Initiation of development of diapausing embryo by mammary denervation during lactation in a marsupial. Nature $\mathbf{2 7 8}$ $549-551$

Renfree MB \& Tyndale-Biscoe CH 1973 Intrauterine development after diapause in the marsupial Macropus eugenii. Developmental Biology 32 28-40.

Renfree MB \& Lewis AM 1996 Cleavage in vivo and in vitro in the marsupial Macropus eugenii. Reproduction, Fertility and Development 8 725-742.

Renfree MB, Fletcher TP, Blanden DR, Lewis PR, Shaw G, Gordon K, Short RV, Parer-Cook E \& Parer D 1989 Physiological and behavioural events around the time of birth in macropodid marsupials. In Kangaroos, Wallabies and Rat-Kangaroos, pp 323-337. Eds G Grigg, P Jarman \& I Hume. New South Wales: Surrey Beatty \& Sons Pty Limited.

Roth C, Schriecker M, Lakomek M, Strege A, Heiden I, Luft $\mathbf{H}$, Munzel U, Wuttke W \& Jarry H 2001 Autoregulation of the gonadotrophin-releasing hormone $(\mathrm{GnRH})$ system during puberty: effects of antagonistic versus agonistic GnRH analogs in a female rat model. Journal of Endocrinology 169 361-371.

Rudd CD 1994 Sexual behaviour of male and female tammar wallabies (Macropus eugenii) at post-partum oestrus. Journal of Zoology $232151-162$. 
Sadleir RM \& Tyndale-Biscoe CH 1977 Photoperiod and the termination of embryonic diapause in the marsupial Macropus eugenii. Biology of Reproduction 16 605-608.

Shaw G \& Renfree MB 1984 Concentrations of oestradiol-17 beta in plasma and corpora lutea throughout pregnancy in the tammar, Macropus eugenii. Journal of Reproduction and Fertility 72 29-37.

Short RV, Flint AP \& Renfree MB 1985 Influence of passive immunization against $\mathrm{GnRH}$ on pregnancy and parturition in the tammar wallaby, Macropus eugenii. Journal of Reproduction and Fertility $75567-575$.

Sutherland RL, Evans SM \& Tyndale-Biscoe CH 1980 Macropodid marsupial luteinizing hormone: validation of assay procedures and changes in concentrations in plasma during the oestrous cycle in the female tammar wallaby (Macropus eugenii). Journal of Endocrinology 86 1-12.

Trigg TE, Wright PJ, Armour AF, Williamson PE, Junaidi A, Martin GB, Doyle AG \& Walsh J 2001 Use of a GnRH analogue implant to produce reversible long-term suppression of reproductive function in male and female domestic dogs. Journal of Reproduction and Fertility Supplement 57 255-261.

Tyndale-Biscoe CH \& Renfree MB 1987 In Reproductive Physiology of Marsupials. Cambridge: Cambridge University Press.

Tyndale-Biscoe CH \& Janssens PA (eds) 1988 The Developing Marsupial. Models for Biomedical Research. Berlin: Springer-Verlag.

Tyndale-Biscoe CH, Hearn JP \& Renfree MB 1974 Control of reproduction in macropodid marsupials. Journal of Endocrinology 63 589-614.

Tyndale-Biscoe CH, Hinds LA, Horn CA \& Jenkin G 1983 Hormonal changes at oestrus, parturition and post-partum oestrus in the tammar wallaby (Macropus eugenii). Journal of Endocrinology 96 155-161.

Received 18 June 2003

First decision 13 October 2003

Accepted 12 November 2003 